\title{
Dietary factors associated with metabolic syndrome in Brazilian adults
}

\author{
Erick Prado de Oliveira ${ }^{1,24^{*}}$, Kátia Cristina Portero McLellan ${ }^{1}$, Liciana Vaz de Arruda Silveira ${ }^{3}$ and \\ Roberto Carlos Burini ${ }^{1}$
}

\begin{abstract}
Background: Metabolic Syndrome (MS) is defined as the association of numerous factors that increase cardiovascular risk and diet is one of the main factors related to increase the MS in the population. This study aimed to evaluate the association of diet on the presence of MS in an adult population sample.

Methodology: 305 adults were clinically screened to participate in a lifestyle modification program. Anthropometric assessments included waist circumference (WC), body fat and calculated BMI $\left(\mathrm{kg} / \mathrm{m}^{2}\right)$ and musclemass index $\left(\mathrm{MMl} \mathrm{kg} / \mathrm{m}^{2}\right)$. Dietary intake was estimated by $24 \mathrm{~h}$ dietary recall. Fasting blood was used for biochemical analysis. MS was diagnosed using NCEP-ATPIII (2001) criteria with adaptation for glucose ( $\geq 100 \mathrm{mg}$ / $\mathrm{dL}$ ). Logistic regression (Odds ratio) was performed in order to determine the odds ratio for developing MS according to dietary intake.
\end{abstract}

Results: An adequate intake of fruits, $\mathrm{OR}=0.52$ (Cl:0.28-0.98), and an intake of more than 8 different items in the diet (variety), $\mathrm{OR}=0.31$ (Cl:0.12-0.79) showed to be a protective factor against a diagnosis of MS. Saturated fat intake greater than 10\% of total caloric value represented a risk for MS diagnosis, OR = 2.0 (1.04-3.84).

Conclusion: Regarding the dietary aspect, a risk factor for MS was higher intake of saturated fat, and protective factors were high diet variety and adequate fruit intake.

Keywords: Diet, Metabolic Syndrome, Diet variety, Fruit intake, Saturated fat

\section{Background}

Metabolic Syndrome (MS) is defined as the association of numerous factors that increase cardiovascular risk [1], such as dyslipidemia, abdominal obesity, systemic arterial hypertension and impaired fasting glycemia. All these altered factors are related to a prothrombotic and proinflammatory condition $[2,3]$.

MS prevalence in the United States is 21.8\% [4], and it has increased strongly over the last few years [5]. In Brazil, no data have been reported for the national prevalence, but some studies have shown that MS prevalence at a regional level is approximately 15.8 to $48.3 \%[6,7]$.

It is known that MS etiology includes genetic, metabolic and environmental factors [8]. Among

\footnotetext{
* Correspondence: erick_po@yahoo.com.br

${ }^{1}$ Center for exercise metabolism and nutrition (CeMENutri), Department of

Public Health, Botucatu School of Medicine (UNESP), Botucatu, Brazil
}

Full list of author information is available at the end of the article environmental factors, diet is one of the main aspects related to the increase in MS in the population [9].

The western diet, which is characterized by the intake of processed meat, refined grains, fried meat and sugarbased desserts, is directly associated with the risk of MS [10]. On the other hand, the Mediterranean diet has been inversely associated with MS development [11]. Epidemiological studies and control cases have shown a protective effect from dietary patterns characterized by the intake of vegetables, fruit, legumes, whole grain, fiber, fish, lean meat, poultry and fat-free dairy products $[12,13]$.

Studies have shown that some dietary components directly influence MS, both as protective factors [11,14] and as risk factors $[15,16]$. However, no Brazilian study has investigated the influence of dietary intake on MS, only on isolated MS components [17-19]. Therefore, the aim of this study was to evaluate dietary influence on MS in an adult population sample.

\section{Biomed Central}




\section{Methods Individuals}

This is a descriptive cross-sectional study conducted from 2004 to 2008 on a sub-group of participants clinically selected and enrolled for the lifestyle modification program "Mexa-se Pró-Saúde" (Move for Health), described in elsewhere [1]. All individuals that had all the MS components data were included to the study. A convenience sample were consisted of three hundred and five individuals, with MS (39.7\%) or not, males and females, aged $>35$ years, were evaluated. All the participants have never participated of any program of lifestyle change before and signed an informed-consent form, which, conjointly with the project, was approved by the Research Ethics Committee (document no. CEP 32712009) of the Botucatu School of Medicine (FMB UNESP).

\section{Marital status}

Marital status was classified as single + divorced vs married + cohabiting. Educational level was evaluated as complete and incomplete secondary and college education vs illiterate, complete and incomplete primary education. Family income $\geq 6$ minimum salaries vs $<6$ minimum salaries.

\section{Body composition}

The anthropometric assessment consisted of measuring body weight and height, according to the previously described procedures [20], followed by BMI estimation. Waist circumference (WC) was measured by a nonextensible and non-elastic millimeter-graded measuring tape. Measurement was made on the mid-point between the last intercostal space and the iliac crest. The reference values proposed by NCEP-ATP III $[21,22]$ were used and WC larger than $88 \mathrm{~cm}$ for females and 102 for males was considered to be increased [21].

Bioelectric impedance (Biodynamics ${ }^{\circledR}$, model 450, USA) was used to determine the percentage of body fat (\%BF) and muscle mass (kg). Segal et al (1988) equation was used to calculated the \%BF [23]. The muscle mass ( $\mathrm{kg}$ ) was obtained using the Janssen et al., (2000) equation [24] and the muscle mass index (MMI) was calculated as MM $(\mathrm{kg}) / \mathrm{height}^{2}$.

\section{Clinical evaluation of arterial blood pressure}

Systolic and diastolic arterial blood pressure was evaluated with the individual in the seated position according to the procedures described by the V Brazilian Guidelines on Arterial Hypertension [25]. Values of systolic blood pressure $\geq 130 \mathrm{~mm} \mathrm{Hg}$ and/or diastolic blood pressure $\geq 85 \mathrm{~mm} \mathrm{Hg}$ were considered abnormal.

\section{Biochemical analyses}

For biochemical analyses, the individuals were submitted to blood sample collections after nocturnal fasting ( 8 a 12 hours) by standard venipuncture. Glucose, triglycerides (TG) and high-density lipoprotein cholesterol (HDL-c) concentrations were quantified in serum by the dry chemistry method. The classification of normality levels followed NCEP-ATPIII $[21,22]$.

\section{MS diagnosis}

The individuals were diagnosed as having MS according to NCEP-ATP III [21,22], with glycemia levels adapted for $100 \mathrm{mg} / \mathrm{dL}$ [26].

The five components used were plasma concentrations of triglycerides, HDL-c and fasting glucose, arterial hypertension and abdominal circumference. MS was diagnosed when three or more of these components were altered.

\section{Dietary intake assesment}

The $24 \mathrm{~h}$ dietary recall was used to assess food intake [27]. Dietary data obtained in homemade measurements were converted into grams and milliliters to permit chemical analysis of food intake. The centesimal composition of foods present in the records was calculated using NutWin ${ }^{\circledR}$ (2002) software, version 1.5. Foods not found in the software were added from diverse composition tables and food labels [28,29]. Diet quality was evaluated using the Adapted Healthy Eating Index (HEI) [30] and evaluated groups were based on portions recommended by the Adapted Food Pyramid [31].

\section{Statistical analysis}

The analyses were performed by using SAS, version 9.1, and STATISTICA 6.0. The data were described as mean $\pm \mathrm{SD}$ and median and interquartile interval. Sample normality was tested by means of the Shapiro-Wilk test. For comparison of individuals with or without MS, the $t$ test was used for normal distribution. Wilcoxon analysis for not-normal distribution, and the Chi-square test for categorical variables. In order to correlate the dietary variables with the number of MS components and with each component isolated, partial pearson's correlation was used (adjusted for gender, age, total caloric value (TCV) and BMI). Logistic regression (odds ratio) was performed, with a confidence interval (CI) of 95\%, in order to evaluate the odds ratio for developing MS according to dietary intake. Two models were used, and the first was adjusted for gender and age; the second was additionally adjusted for TCV and BMI. The results were discussed based on the level of significance of $p<$ 0.05 . 


\section{Results}

The individuals with MS were older and showed poorer education than those without MS. Income, marital status and gender were similar in both groups. As regards body composition, the individuals with MS showed higher adiposity (> BMI and \%BF) and higher MMI. Additionally, lower intake of fruit servings and smaller variety was observed in the diet of individuals with MS (Table 1).

A positive and weak $(r<0.3)$ correlation was observed among the number of altered MS components, sugar and total lipid intake whereas a negative and week correlation was found between carbohydrate \% and the number of fruit servings $(p<0.05)$. All the other dietary variables did not correlate $(p>0.05)$.

It was observed that adequate intake of fruit servings and diet variety $\geq 8$ food items showed a protective effect for SM. Intake higher than 10\% of TCV of saturated fat was found to be a risk factor (Table 2).
In order to explain the protective factor of diet variety for MS, a correlation was made between diet variety and the intake of macronutrients and groups on the food pyramid to evaluate what is the intake profile of individuals who ingested a higher number of different food types. Hence, a positive correlation between diet variety and the intake of vegetables $(\mathrm{r}=0.34 ; p<0.05)$, fruit $(\mathrm{r}$ $=0.32 ; p<0.05)$, fibers $(\mathrm{r}=0.22 ; p<0.05)$, dairy products $(\mathrm{r}=0.20 ; p<0.05)$ and HEI $(\mathrm{r}=0.20 ; p<0.05)$ was observed, and a negative correlation for the intake of legumes $(r=-0.11 ; p<0.05)$, meat $(r=-0.15 ; p<$ $0.05)$ and grains $(\mathrm{r}=-0.19 ; p<0.05)$ was found. There wasn't a significant correlation for the intake of macronutrients, oil servings and sugar.

\section{Discussion}

The main finding of the present investigation was the protective effect of fruit intake and increase in diet

Table 1 Demographic, body-composition and dietary characteristics of individuals with and without the Metabolic Syndrome (MS).

\begin{tabular}{|c|c|c|c|}
\hline & Without MS $(n=184)$ & With MS $(n=121)$ & $p$ \\
\hline Age (years) & $54.2 \pm 10$ & $55.8 \pm 10$ & $<0.0001$ \\
\hline$\%$ females & 73.4 & 73.5 & 0.96 \\
\hline Marital status (single + divorced) & $47.4 \%$ & $57.5 \%$ & 0.08 \\
\hline Education (illiterate; complete and incomplete elementary school) & $46.7 \%$ & $61.1 \%$ & 0.01 \\
\hline Income (> 6 minimum salaries) & $44 \%$ & $37.5 \%$ & 0.29 \\
\hline BMI $\left(\mathrm{kg} / \mathrm{m}^{2}\right)$ & $27.5 \pm 4.7$ & $31.5 \pm 4.7$ & $<0.0001$ \\
\hline \%Body Fat & $30.6 \pm 8$ & $36.5 \pm 5$ & $<0.0001$ \\
\hline Muscle Mass Index & $8.2 \pm 1.5$ & $8.8 \pm 1.7$ & 0.0004 \\
\hline TCV (kcal) & $1520 \pm 578$ & $1521 \pm 708$ & 0.99 \\
\hline$\%$ Carbohydrate & $52.3 \pm 9.2$ & $50.5 \pm 9.2$ & 0.08 \\
\hline$\%$ Protein & $18.4 \pm 5.4$ & $18.9 \pm 6.2$ & 0.44 \\
\hline$\%$ Total lipid & $29.2 \pm 8.6$ & $30.7 \pm 8.1$ & 0.14 \\
\hline$\%$ Saturated lipid & $7.5(5.2-10.3)$ & $7.6(5.7-9.6)$ & 0.66 \\
\hline$\%$ Monounsaturated lipid & $8.3(6.3-10.6)$ & $8.9(6.8-11.7)$ & 0.18 \\
\hline$\%$ Polyunsaturated lipid & $6.8(4.8-9.2)$ & $7.5(5.4-9.7)$ & 0.09 \\
\hline Cholesterol (mg) & $133(89-214)$ & $138(87-204)$ & 0.69 \\
\hline Fibers (g) & $13.6(8.6-19)$ & $12.6(7.5-19)$ & 0.31 \\
\hline HEI (score) & $82.7 \pm 14$ & $81.2 \pm 13$ & 0.32 \\
\hline Oil (number of servings) & $1.5(1.0-2.5)$ & $1.5(1.0-3.0)$ & 0.63 \\
\hline Grains (number of servings) & $3.0(2.4-4.0)$ & $3.0(2.0-4.0)$ & 0.62 \\
\hline Fruit (number of servings) & $2.5(0.4-4.5)$ & $1.4(0.0-3.5)$ & 0.01 \\
\hline Vegetables (number of servings) & $1.5(0.5-3.0)$ & $1.5(0.5-2.6)$ & 0.8 \\
\hline Legumes (number of servings) & $1.0(0.3-2.0)$ & $1.0(0.4-1.5)$ & 0.32 \\
\hline Dairy products (number of servings) & $1.4(0.5-2.0)$ & $1.0(0.5-2.0)$ & 0.64 \\
\hline Meat (number of servings) & $1.5(1.0-2.5)$ & $1.5(1.0-2.0)$ & 0.72 \\
\hline Sugar (number of servings) & $1.0(0.06-2.0)$ & $1.0(0.4-2.0)$ & 0.6 \\
\hline Variety & $12.0(10-15)$ & $11.0(9.0-15)$ & 0.026 \\
\hline
\end{tabular}

BMI = Body Mass Index; TCV = Total Caloric Value; HEI = Healthy Diet Index; LDL-c = Low-Density Lipoprotein cholesterol

Data expressed in mean \pm SD or median and interquartile interval 
Table 2 Odds ratio for MS according to dietary intake.

\begin{tabular}{|c|c|c|}
\hline & \multicolumn{2}{|c|}{ MS } \\
\hline & Odds ratio $(95 \% \mathrm{Cl})$ & Odds ratio $(95 \% \mathrm{Cl})$ \\
\hline & Model 1 & Model 2 \\
\hline$\%$ Carbohydrate (<50 vs $>60 \%)$ & $1.6(0.72-3.57)$ & $0.64(0.28-1.45)$ \\
\hline \%Carbohydrate (50-60 vs > 60\%) & $1.2(0.52-2.8)$ & $0.65(0.27-1.59)$ \\
\hline \%Protein ( $\leq 15$ vs $>15)$ & $0.6(0.31-1.15)$ & $1.59(0.80-3.14)$ \\
\hline \%Total lipid ( $\leq 35$ vs $>35$ ) & $0.92(0.49-1.7)$ & $0.91(0.48-1.72)$ \\
\hline$\%$ Saturated lipid (> 10\% vs $\leq 10 \%$ ) & $0.62(0.34-1.17)$ & $2.0(1.04-3.84)^{*}$ \\
\hline \%Polyunsaturated lipid ( $\leq 10 \%$ vs $>10 \%$ ) & $1.22(0.66-2.27)$ & $1.25(0.66-2.39)$ \\
\hline Cholesterol ( $\leq 300 \mathrm{mg}$ vs $>300 \mathrm{mg})$ & $0.91(0.38-2.19)$ & $0.69(0.25-1.91)$ \\
\hline Fibers $(\geq 20 \mathrm{~g}$ vs $<20 \mathrm{~g})$ & $0.75(0.38-1.46)$ & $0.67(0.32-1.38)$ \\
\hline HEI (good vs. bad) & $0.91(0.27-3.07)$ & $0.88(0.24-3.19)$ \\
\hline Oil servings ( $\leq 2$ vs $>2$ ) & $1.3(0.73-2.34)$ & $1.18(0.60-2.32)$ \\
\hline Grains servings ( $\geq 5$ vs $<5$ ) & $1.15(0.54-2.47)$ & $1.40(0.58-1.41)$ \\
\hline Fruit servings ( $\geq 3$ vs $<3$ ) & $0.53(0.29-0.97)^{*}$ & $0.52(0.28-0.98)^{*}$ \\
\hline Vegetable servings ( $\geq 4$ vs $<4$ ) & $1.0(0.24-4.17)$ & $0.97(0.22-4.27)$ \\
\hline Legume servings $(\geq 1$ vs $<1$ ) & $0.67(0.39-1.17)$ & $0.69(0.39-1.24)$ \\
\hline Dairy product servings ( $\geq 3$ vs $<3$ ) & $1.45(0.60-3.44)$ & $1.6(0.64-4.03)$ \\
\hline Meat servings $(\leq 2$ vs $>2)$ & $1.24(0.65-2.38)$ & $1.22(0.58-2.55)$ \\
\hline Sugar servings ( $\leq 2$ vs $>2$ ) & $1.01(0.52-1.96)$ & $0.82(0.38-1.78)$ \\
\hline Dietary variety ( $\geq 8$ vs $<8$ ) & $0.41(0.18-0.91)^{*}$ & $0.31(0.12-0.79)^{*}$ \\
\hline
\end{tabular}

Model 1: Adjusted for gender and age

Model 2: Model1+ BMI and TCV

* $\mathrm{p}<0.05$

variety and the harmful effect of saturated fat intake on the chances of developing MS.

Levy-Costa et al. (2005) observed the presence of excessive sugar and saturated fat intake and insufficient fruit and vegetable intake in the Brazilian diet [32]. Our results appear to confirm that this dietary habit is directly associated with the higher risk for MS in this population.

Other studies have shown a protective effect from fruit intake against MS [33-35], indicating that such intake is related to the reduction of almost all MS components (TG, hypertension, WC and glucose) $[18,34]$. The main protective factor from fruit probably results from the intake of soluble fibers [33]. The intake of this fiber type can reduce glycemia from lower absorption and digestion of carbohydrates, thus reducing insulin secretion, in addition to reducing dyslipidemia [36]. Additionally, the potassium present in this food type can also reduce arterial pressure [37]. The intake of food with low glycemic loads, such as fruit, is related to smaller WC [38], possibly due to the greater satiation [39] and lower energy density provided by this food type [40].

When the diet is evaluated as a whole, the food patterns that are characterized by large amounts of fruit, vegetables and whole grains, such as the Mediterranean diet, are inversely associated with MS prevalence
[11,41-43] whereas the western diet, characterized by low fruit intake, is positively associated with MS [10].

Another protective factor identified in the present study was diet variety, evaluated by the number of different food types ingested in $24 \mathrm{~h}$. To our knowledge, this is the first study reporting diet variety as a protective factor against MS development, and further studies are necessary to explain the possible mechanisms involved. Analysis of the results showed that greater diet variety was correlated with a better quality diet (HEI) and with food groups considered to be healthy, such as the intake of vegetables, fruit, fibers and dairy products. These food groups have been reported by other studies as prevalence reducers and protective factors against MS development [33,34,37,39,44,45]. Furthermore, the diet variety could be influenced for the fruit intake isolated, which is also a protector factor for MS. The present study also identified an inverse correlation of diet variety with meat intake, thus showing that this food type increases the chances for MS development [15].

A study conducted with older individuals showed that the inadequate intakes of several nutrients were associated with lower diet variety. It means that recommendations to increase diet variety may be necessary for elderly people to achieve adequate nutrient intakes [46]. 
Another possible cause for the protective effect of diet variety could be the fact that the individuals whose had the higher diet varied showed greater fractioning during the evaluated day. Studies show that increased fractioning is responsible for decreasing fasting glycemia [47], plasma concentration of postprandial insulin, plasma concentrations of LDL-c and total cholesterol [48]. Additionally, greater fractioning increases postprandial thermogenesis [48] and can foster the negative energy balance, thus providing weight loss in the long term and as a positive factor for MS reduction.

The present study showed increased chances of MS development in individuals who ingest $>10 \%$ of saturated fat $\mathrm{TCV}$. This association may have occurred due to the fact saturated fat increases the visceral adipose tissue in greater proportion than other fat types, since it reduces the activation of PGC- $1 \alpha$ (PPAR $\gamma$-coactivator), an important oxidative metabolism regulator. Thus, fatty acid and glucose oxidation is decreased, and accumulation in tissues and circulation is increased [49]. Hence, saturated fat intake would increase the visceral adipose tissue, which contributes to MS development.

Additionally, saturated fat increases insulin resistance (IR) compared to monounsaturated fat [50], because it activates serine kinases, thus inhibiting the insulin phosphorylation cascade, decreasing glucose uptake and increasing glycemia [51]. Another contributing factor to IR is the increase in inflammation, apoptosis and oxidative stress of adipocytes [49].

Some epidemiological studies showed that total dietary fat intake is positively associated with MS in Japanese Brazilian populations [52] and in other countries [16], and this positive association is directly related to saturated fat [53], which is in agreement with our results.

The present study showed that individuals with MS had poorer education, were older and presented higher adiposity (BMI, \%BF and WC) and muscle mass (MMI). Another studied reported a positive correlation between BMI and muscle mass, showing that obese individuals present not only higher fat mass, but also show higher muscle mass $(\mathrm{kg})$ [54].

Epidemiological studies have shown the influence of age on MS $[55,56]$, and this occurs due to the fact that ageing is related to body fat mass and lean mass redistribution with rapid increase in visceral intra-abdominal fat, which is proinflammatory and related to insulin resistance [57].

The relation between poorer education and hyperadiposity has been observed by other studies [58]. This relation can be explained by the fact that individuals with poorer education consume less fruit, vegetables and legumes; i.e. their diet is of lower quality [59]. The intake of these food groups were protective factors against MS in the present study.
The present study has some limitations. For this research has used the convenience sample, it do not allow generalizations for the Brazilian population. Furthermore, results from several studies using different food inquiry techniques showed underestimation in intake reports, both in males and females. However, the underestimation is primarily identified among obese individuals and particularly among females [60]. Considering that all the methods that evaluate dietary intake are, to some extent, imperfect and that a gold standard does not exist in nutrition, patient diet was evaluated by analysis of 24-hour recalls. This fact represents the principal limitation in our study, since one 24-hour recalls do not detect dietary intake variations.

\section{Conclusion}

In this study, recommended intake of fruit and high diet variety are protective factors and high intake of saturated fat is a risk factor for metabolic syndrome.

Future proposals for intervention should consider lifestyle changes with adequate eating habits in these individuals.

\section{Abbreviations}

BMl: Body mass index; MS: Metabolic syndrome; WC: Waist circumference; NCEP-ATPIII: National cholesterol education program-adult treatment painel III; HEl: Healthy eating index; TCV: Total caloric value; HDL: High density lipoprotein cholesterol; TG: Triglycerides.

\section{Author details}

${ }^{1}$ Center for exercise metabolism and nutrition (CeMENutri), Department of Public Health, Botucatu School of Medicine (UNESP), Botucatu, Brazil. ${ }^{2}$ Department of Pathology, Botucatu School of Medicine (UNESP), Botucatu, Brazil. ${ }^{3}$ Department of Bioestatistic, Bioscience Institute (UNESP), Botucatu, Brazil. ${ }^{4}$ CeMENutri - Faculdade de Medicina, Depto. de Saúde Pública (FMB UNESP), Distrito de Rubião Jr, s/nº 18.618-970, Botucatu, SP, Brazil.

\section{Authors' contributions}

EPO wrote the manuscript, KCPM corrected and revised the final manuscript. LVAS made the statistical analysis and corrected the manuscript. RCB was the mentor of the work and advisor of the authors. All authors read and approved the final manuscript.

\section{Competing interests}

The authors declare that they have no competing interests.

Received: 3 October 2011 Accepted: 14 March 2012 Published: 14 March 2012

\section{References}

1. Takahashi MM, de Oliveira EP, de Carvalho AL, Dantas LA, Burini FH, Portero-McLellan KC, Burini RC: Metabolic Syndrome and dietary components are associated with coronary artery disease risk score in free-living adults: a cross-sectional study. Diabetol Metab Syndr 2011, 3:7.

2. Orsatti FL, Nahas EA, Orsatti $C L$, de Oliveira EP, Nahas-Neto J, da Mota GR, Burini RC: Muscle mass gain after resistance training is inversely correlated with trunk adiposity gain in postmenopausal women. J Strength Cond Res 2011, [Epub ahead of print].

3. Grundy SM: Metabolic syndrome: connecting and reconciling cardiovascular and diabetes worlds. J Am Coll Cardiol 2006, 47:1093-1100.

4. Ford ES, Giles WH, Dietz WH: Prevalence of the metabolic syndrome among US adults: findings from the third National Health and Nutrition Examination Survey. JAMA 2002, 287:356-359. 
5. Ford ES, Giles WH, Mokdad AH: Increasing prevalence of the metabolic syndrome among u.s. Adults. Diabetes Care 2004, 27:2444-2449,

6. Salaroli LB, Barbosa GC, Mill JG, Molina MC: Prevalence of metabolic syndrome in population-based study, Vitoria, ES-Brazil. Ara Bras Endocrinol Metabol 2007, 51:1143-1152.

7. Velasquez-Melendez G, Gazzinelli A, Correa-Oliveira R, Pimenta AM, Kac G: Prevalence of metabolic syndrome in a rural area of Brazil. Sao Paulo Med J 2007, 125:155-162.

8. Mirmiran P, Noori N, Azizi F: A prospective study of determinants of the metabolic syndrome in adults. Nutr Metab Cardiovasc Dis 2008, 18:567-573.

9. Buckland G, Salas-Salvado J, Roure E, Bullo M, Serra-Majem L:

Sociodemographic risk factors associated with metabolic syndrome in a Mediterranean population. Public Health Nutr 2008, 11:1372-1378.

10. Lutsey PL, Steffen LM, Stevens J: Dietary intake and the development of the metabolic syndrome: the Atherosclerosis Risk in Communities study. Circulation 2008, 117:754-761.

11. Babio N, Bullo M, Basora J, Martinez-Gonzalez MA, Fernandez-Ballart J, Marquez-Sandoval F, Molina C, Salas-Salvado J: Adherence to the Mediterranean diet and risk of metabolic syndrome and its components. Nutr Metab Cardiovasc Dis 2009, 19:563-570.

12. Lichtenstein AH, Appel L, Brands M, Carnethon M, Daniels S, Franch HA Franklin B, Kris-Etherton P, Harris WS, Howard B, et al: Diet and lifestyle recommendations revision 2006: a scientific statement from the American Heart Association Nutrition Committee. Circulation 2006, 114:82-96

13. Katcher HI, Hill AM, Lanford JL, Yoo JS, Kris-Etherton PM: Lifestyle approaches and dietary strategies to lower LDL-cholesterol and triglycerides and raise HDL-cholesterol. Endocrinol Metab Clin North Am 2009, 38:45-78.

14. Aleixandre A, Miguel M: Dietary fiber in the prevention and treatment of metabolic syndrome: a review. Crit Rev Food Sci Nutr 2008, 48:905-912.

15. Azadbakht L, Esmaillzadeh A: Red meat intake is associated with metabolic syndrome and the plasma C-reactive protein concentration in women. J Nutr 2009, 139:335-339.

16. Chen X, Pang Z, Li K: Dietary fat, sedentary behaviors and the prevalence of the metabolic syndrome among Qingdao adults. Nutr Metab Cardiovasc Dis 2009, 19:27-34.

17. de Oliveira EP, Manda RM, Torezan GA, Corrente JE, Burini RC: Dietary, anthropometric, and biochemical determinants of plasma high-density lipoprotein-cholesterol in free-living adults. Cholesterol 2011, 2011:851750.

18. Takahashi MM, de Oliveira EP, Moreto F, Portero-McLellan KC, Burini RC: Association of dyslipidemia with intakes of fruit and vegetables and the body fat content of adults clinically selected for a lifestyle modification program. Arch Latinoam Nutr 2010, 60:148-154.

19. Pimentel GD, Portero-McLellan KC, de Oliveira EP, Spada AP, Oshiiwa M, Zemdegs JC, Barbalho SM: Long-term nutrition education reduces several risk factors for type 2 diabetes mellitus in Brazilians with impaired glucose tolerance. Nutr Res 2010, 30:186-190.

20. Heyward VH, Stolarczyk LM: Avaliação da composição corporal aplicada. 1 edition. São Paulo; 2000.

21. Executive Summary of The Third Report of The National Cholesterol Education Program (NCEP) Expert Panel on Detection, Evaluation, And Treatment of High Blood Cholesterol In Adults (Adult Treatment Panel III). Jama 2001, 285:2486-2497.

22. Third Report of the National Cholesterol Education Program (NCEP) Expert Panel on Detection, Evaluation, and Treatment of High Blood Cholesterol in Adults (Adult Treatment Panel III) final report. Circulation 2002, 106:3143-3421

23. Segal KR, Van Loan M, Fitzgerald Pl, Hodgdon JA, Van Itallie TB: Lean body mass estimation by bioelectrical impedance analysis: a four-site crossvalidation study. Am J Clin Nutr 1988, 47:7-14

24. Janssen I, Heymsfield SB, Baumgartner RN, Ross R: Estimation of skeletal muscle mass by bioelectrical impedance analysis. J Appl Physiol 2000, 89:465-471.

25. V Diretrizes Brasileiras de Hipertensão Arterial. Revista da Sociedade Brasileira de Cardiologia 2005, 84.

26. Grundy SM, Brewer HB Jr, Cleeman Jl, Smith SC Jr, Lenfant C: Definition of metabolic syndrome: report of the National Heart, Lung, and Blood Institute/American Heart Association conference on scientific issues related to definition. Arterioscler Thromb Vasc Biol 2004, 24:e13-e18.
27. Fisberg RM, Slater B, Marchioni DML, Martini LA: Inquéritos Alimentares -Métodos e Bases Científico. Barueri: Manole; 2005.

28. NEPA/UNICAMP: Tabela brasileira de composição de alimentos. Taco. Versão 1. Campinas; 2004.

29. Philippi ST: Tabela de Composição de Alimentos: Suporte para decisão nutricional. São Paulo; 22002.

30. Mota JF, Rinaldi AEM, Pereira AF, Maestá N, Scarpin MM, Burini RC Adaptation of the healthy eating index to the food guide of the Brazilian population. Rev Nutri 2008, 21:545-552.

31. Philippi ST, Latterza AR, Cruz ATR, Ribeiro LC: Adapted food pyramid: a guide for a right food choice. Rev Nutri 1999, 12:65-80.

32. Levy-Costa RB, Sichieri R, Pontes Ndos S, Monteiro CA: Household food availability in Brazil: distribution and trends (1974-2003). Rev Saude Publica 2005, 39:530-540.

33. Steemburgo T, Dall'Alba V, Almeida JC, Zelmanovitz T, Gross JL, de Azevedo MJ: Intake of soluble fibers has a protective role for the presence of metabolic syndrome in patients with type 2 diabetes. Eur Clin Nutr 2009, 63:127-133.

34. Esmaillzadeh A, Kimiagar M, Mehrabi Y, Azadbakht L, Hu FB, Willett WC: Fruit and vegetable intakes, C-reactive protein, and the metabolic syndrome. Am J Clin Nutr 2006, 84:1489-1497.

35. Shin A, Lim SY, Sung J, Shin HR, Kim J: Dietary intake, eating habits, and metabolic syndrome in Korean men. J Am Diet Assoc 2009, 109:633-640.

36. Riccardi G, Rivellese AA: Effects of dietary fiber and carbohydrate on glucose and lipoprotein metabolism in diabetic patients. Diabetes Care 1991, 14:1115-1125.

37. He J, Streiffer RH, Muntner P, Krousel-Wood MA, Whelton PK: Effect of dietary fiber intake on blood pressure: a randomized, double-blind, placebo-controlled trial. J Hypertens 2004, 22:73-80.

38. Toeller M, Buyken AE, Heitkamp G, Cathelineau G, Ferriss B, Michel G: Nutrient intakes as predictors of body weight in European people with type 1 diabetes. Int J Obes Relat Metab Disord 2001, 25:1815-1822.

39. Kimm SY: The role of dietary fiber in the development and treatment of childhood obesity. Pediatrics 1995, 96:1010-1014

40. Rolls BJ, Bell EA: Intake of fat and carbohydrate: role of energy density. Eur J Clin Nutr 1999, 53(Suppl 1):S166-S173.

41. Lerman RH, Minich DM, Darland G, Lamb JJ, Schiltz B, Babish JG, Bland JS, Tripp ML: Enhancement of a modified Mediterranean-style, low glycemic load diet with specific phytochemicals improves cardiometabolic risk factors in subjects with metabolic syndrome and hypercholesterolemia in a randomized trial. Nutr Metab (Lond) 2008, 5:29.

42. Salas-Salvado J, Fernandez-Ballart J, Ros E, Martinez-Gonzalez MA, Fito M, Estruch R, Corella D, Fiol M, Gomez-Gracia E, Aros F, et al: Effect of a Mediterranean diet supplemented with nuts on metabolic syndrome status: one-year results of the PREDIMED randomized trial. Arch Intern Med 2008, 168:2449-2458

43. Tortosa A, Bes-Rastrollo M, Sanchez-Villegas A, Basterra-Gortari FJ, NunezCordoba JM, Martinez-Gonzalez MA: Mediterranean diet inversely associated with the incidence of metabolic syndrome: the SUN prospective cohort. Diabetes Care 2007, 30:2957-2959.

44. Esposito K, Giugliano D: Mediterranean dietary patterns and chronic diseases. Am J Clin Nutr 2008, 88:1179-1180, author reply 1180-1171.

45. van Meijl LE, Vrolix R, Mensink RP: Dairy product consumption and the metabolic syndrome. Nutr Res Rev 2008, 21:148-157.

46. Marshall TA, Stumbo PJ, Warren JJ, Xie XJ: Inadequate nutrient intakes are common and are associated with low diet variety in rural, communitydwelling elderly. J Nutr 2001, 131:2192-2196.

47. Carlson O, Martin B, Stote KS, Golden E, Maudsley S, Najjar SS, Ferrucci L, Ingram DK, Longo DL, Rumpler W, et al: Impact of reduced meal frequency without caloric restriction on glucose regulation in healthy, normal-weight middle-aged men and women. Metabolism 2007, 56:1729-1734.

48. Farshchi HR, Taylor MA, Macdonald IA: Beneficial metabolic effects of regular meal frequency on dietary thermogenesis, insulin sensitivity, and fasting lipid profiles in healthy obese women. Am J Clin Nutr 2005, 81:16-24.

49. Kennedy A, Martinez K, Chuang CC, LaPoint K, Mclntosh M: Saturated fatty acid-mediated inflammation and insulin resistance in adipose tissue: mechanisms of action and implications. J Nutr 2009, 139:1-4.

50. Lopez S, Bermudez B, Pacheco YM, Villar J, Abia R, Muriana FJ: Distinctive postprandial modulation of beta cell function and insulin sensitivity by 
dietary fats: monounsaturated compared with saturated fatty acids. Am J Clin Nutr 2008, 88:638-644.

51. Hotamisligil GS: Inflammation and metabolic disorders. Nature 2006, 444:860-867.

52. Freire RD, Cardoso MA, Gimeno SG, Ferreira SR: Dietary fat is associated with metabolic syndrome in Japanese Brazilians. Diabetes Care 2005, 28:1779-1785

53. Kume A, Miyazaki T, Kitamura Y, Oshida K, Yanagisawab N, Takizawa H, Fujii K, Kiyanagi T, Sumiyoshi K, Ohmura $H$, et al: High levels of saturated very long-chain fatty acid (hexacosanoic acid; $\mathrm{C} 26: 0$ ) in whole blood are associated with metabolic syndrome in Japanese men. Diabetes Res Clin Pract 2008, 80:259-264.

54. Seidell JC, Bjorntorp P, Sjostrom L, Sannerstedt R, Krotkiewski M, Kvist H: Regional distribution of muscle and fat mass in men-new insight into the risk of abdominal obesity using computed tomography. Int J Obes 1989, 13:289-303.

55. Razzouk L, Muntner P: Ethnic, gender, and age-related differences in patients with the metabolic syndrome. Curr Hypertens Rep 2009, 11:127-132.

56. Kyle UG, Genton L, Hans D, Karsegard L, Slosman DO, Pichard C: Agerelated differences in fat-free mass, skeletal muscle, body cell mass and fat mass between 18 and 94 years. Eur J Clin Nutr 2001, 55:663-672.

57. Beaufrere B, Morio B: Fat and protein redistribution with aging: metabolic considerations. Eur J Clin Nutr 2000, 54(Suppl 3):S48-S53.

58. da Fonseca Mde J, Faerstein E, Chor D, Lopes CS, Andreozzi VL: Associations between schooling, income, and body mass index among public employees at an university in Rio de Janeiro, Brazil: the ProSaude Study. Cad Saude Publica 2006, 22:2359-2367.

59. Malta DC, Cezário AC, Moura Ld, Neto OLdM, Junior JBdS: Building Surveillance and Prevention for Chronic Non Communicable Diseases in the National Unified Health System. Epidemiol Serv Saúde 2006, 15:47-65.

60. Drummond SE, Crombie NE, Cursiter MC, Kirk TR: Evidence that eating frequency is inversely related to body weight status in male, but not female, non-obese adults reporting valid dietary intakes. Int I Obes Relat Metab Disord 1998, 22:105-112.

doi:10.1186/1475-2891-11-13

Cite this article as: de Oliveira et al: Dietary factors associated with metabolic syndrome in Brazilian adults. Nutrition Journal 2012 11:13.

\section{Submit your next manuscript to BioMed Central and take full advantage of:}

- Convenient online submission

- Thorough peer review

- No space constraints or color figure charges

- Immediate publication on acceptance

- Inclusion in PubMed, CAS, Scopus and Google Scholar

- Research which is freely available for redistribution

Submit your manuscript at www.biomedcentral.com/submit 